\title{
Personal Liability Of Director Of A Company In Insolvency \& Investor Frauds Cases
}

\section{Dr. Hina Kausar ${ }^{a}$}

aAssistant Professor, Institute of Business Management, GLA University, Mathura, India. E-mail: hina.kausar@gla.ac.in

Article History: Received: 11 January 2021; Accepted: 27 February 2021; Published online: 5 April 2021

\begin{abstract}
The present paper contributes to the understanding of impact of corporate scams and scandals and understanding the reason how these frauds and white-collar crimes impact the investors trust and business environment as a whole. When these scams occur the trust of investors break with each and every turnout. The impact of such corporate scams is not limited to the company where it took place but to each and every business, be it big corporate units or it be some small-scale businesses by directly impacting the stock exchange where the shares are listed. The authors have also tried to focus upon the issues and problems faced by the investors of the company while the company got involved in corporate scams and to figure out the responsible person of the company who will be held accountable in such kind of cases. The present study is limited to the extent of personal liability of a Director and too specifically in the cases of fraud and insolvency. White collar crimes are everywhere these days and that need to be treated as a growing branch of the Criminal law in India. With increase in the Globalization companies are growing and along with it the stakeholders of the company are also growing, any scam done will step back the investors to invest again and more in the company. Thereby with increase in the market share of a company the director of the Company has to establish an internal mechanism to tackle various white -collar crimes nurtured and how these are dealt in the court of law.
\end{abstract}

Keywords: Frauds Cases, Personal Liability, Various Investors.

\section{Introduction}

India has seen many financial scams and all these financial scams directly breaks the faith of the investors therefore such kind of cases should be assessed in a stricter manner so that we could prevent breach of trust done by the directors while acting on behalf of the companies with various investors.

Present study contributes to the understanding of impact of various corporate scams and investors fraud and analyse the reason how these frauds and white-collar crimes impact the investors trust and business environment on whole. Again, when these scams take place the trust of investors break with each and every turnout and resultantly will consistently break the trust of the potential investors as well. SEBI plays regulatory role as well as well as role of reviving the rules in an aim to plug the loopholes in the security market. Various cases of financial scams like Harshad Mehta's case, Ketan Parekh's, 2 G Spectrum, Coal scam, Roop Bansali scam, along with recent ones like Shradha Scam and Sahara India Parivaar Scam which thrashed the trust of the fellow investors and also bring volatility in security market. Other leading cases like Soloman Vs. A. Soloman \& Co. Ltd $^{1}$ and Royal British Bank Vs. Turquand are of great significance when we talk of crimes in Big Business houses wherein it is difficult to pick a single person as accused in the alleged frauds. The impact of these financial scams is not only limited to the business area it deals in but to each and every similar and ancillary business, be it big corporate units or be it some small-scale businesses by directly impacting the domestic or international stock exchanges where the shares are listed. There is a rise in these white-collar crimes due to boost in the corporate sector in the past few decades and till date there are approximately more than 250 corporate scams taken place since Independence of India and nearly rupees 910,306,234,300,000 which is equal to 20.23 Trillion US Dollar has been lost. ${ }^{2}$

Financial fraud is one of the way of cheating investors to invest in and put impact on comparatively larger number of people for e.g. in Sahara India Parivar's investor fraud case company issued optional fully convertible debentures issued by two companies of the Sahara's group to which SEBI claimed jurisdiction and objected that prior permission was not taken before issuing of these shares and in this dispute, money of various investors was put down at stake. The main issue which was raised by the SEBI is that of Jurisdiction between SEBI and Registrar of Companies (ROC) under the Ministry of Corporate Affairs, from which the two alleged companies of Sahara group has already took permit from ROC and thereby issued Red hearing prospectus with ROC.

${ }^{1}(1897)$ AC 22

210-biggest-corporate-scam-of-indiaavailable at - https://www.thecsclubindia.com (visited on 03-03-2018) 
In leading case of National Westminster PLC Vs. Spectrum plus Ltd. \&Ors. while looking at the welfare of the company's creditors court ordered that once the preferential creditors are paid then only the company can bay others. If we analyse the term scam it comes out to be an intentional act committed to harm or injure others securing an unfair or unlawful gain. The risk of transacting in security market involve settlement problem between the bankers and brokers and which may lead to financial crisis. There are various regulatory provisions which are made to prevent financial crisis but due to various loopholes it causes corporate scams/frauds upon the investors. The leader of the said corporate unit are intensively looked upon and questioned and were investigated as per their responsibility and liability against any such event occurred in the said corporate unit. Various such responsibilities and liabilities are mentioned in companies Act 2013 and Rules issued by other regulatory bodies and is also interpreted by the court of law from time to time.

\section{Defining Director and Managing Director Role and Duties}

The Director of a company and the managing director plays different roles in a company and thereby assigned different duties and have different liabilities. However, the term has to be understood in a wider sense.

\subsection{Role \& Responsibility of the Director}

Director of a company is responsible for day-to-day management of activities of a company and to look after whether the company is abiding to all statutory obligations mentioned in Companies Act, 2013.The role of the director is more than an agent, trustee and manager of a company and therefore they must make sure that all their acts are in the benefit of the company while making sure that all their skills and experience are towards making company a success by promoting and achieving its business objectives.

Director under section $2(34)^{3}$ means "a person who direct a group or associate", whereas in terms of a Company it means a person who directs a group of people who are either heading a particular department or is in-charge of a particular departmental group. The difference between manager and a director of a company is a matter of power, a Directors hold more power and responsibilities than a manger of a departmental group. A Director is chosen from the group of managers in that Company. A company can have more than one Director and it is compulsory for every director to take DIN No. (Director Identification Number) which is unique identification number of a director and is unique for each and every director.

The Companies Act, 2013 defines the obligations, provisions relating to appointment, resignation, removal, disqualification, duties and removal of a director in its various provisions. The Companies Act, 2013 defines director as a "Director appointed to the board of a company" and board of directors are defined in section 2(10) as" A collective body of the directors of the company". There are different types of Director such as independent director, residential director, shadow director, nominee director, alternative director, small shareholders director, women director, additional director. The term director is quite different from managing director, as managing director is responsible for day to day maintenance of the operations of the company. In some Countries the term managing director is equivalent to $\mathrm{CEO}$ (Chief operating officer) the executive head of the company. In other countries Managing director works as a head of Individual business unit within a company rather than heading up the company as a whole ${ }^{4}$. Managing director is in-charge of the whole company, from day to day picture to working on a picture of future which is yet to be realised or involves in future picturisation of company's growth. Their role and responsibilities are not specifically defined in the companies Act, 2013 nor the term managing director anywhere in the above Act. In M PitchaiVs. K S Periyaswamy ${ }^{5}$ the board of directors of the company recommended $25 \%$ of the dividend to the shareholders of the company for the financial year 2012-13, though the company incurred loss to the extent of 122.00Crores for the financial year 2012-13, this issue in context of nonwhole time Directors is decided by the Hon'ble court as not justifiable. Court said that vicarious liability of a Director or officer in-charge shall be specific and the burden of proof is upon the Complainant.

The Directors of the company or the person in-charge directly or indirectly use or employ, in connection with the issue, purchase or sale of any securities listed in stock exchange, any manipulative or deceptive device or contrivance in contravention of SEBI Act or the Regulations made there under have necessarily to be dealt in accordance with the provisions of the Act and the Regulations which is absolutely necessary for the investor's protection and to avoid market abuse. ${ }^{6}$

\footnotetext{
${ }^{3}$ The Companies Act, 2013 (India)

${ }^{4}$ www.globalnegotiator.com, accessed on (25-04-2018)

${ }^{5}$ Karnataka High Court CRL. P no. 718/2015, decided on 26.11.2015

${ }^{6} \mathrm{~N}$. Narayanan vs. Adjudicating Officer, SEBI (26.04.2013 - SC): MANU/SC/0426/2013
} 
Responsibility is cast on the Directors to prepare the annual records and reports and those accounts should reflect 'a true and fair view'. The over-riding obligation of the Directors is to approve the accounts only if they are satisfied that they give true and fair view of the profits or loss for the relevant period and the correct financial position of the company. ${ }^{7}$ Director of a Company is also having some fiduciary duty towers the shareholders of the company and the same is bought by court of law in Item Software Vs.Fassihi ${ }^{8}$, in Clark Vs.Cutland, Chaston Vs. SWP Group ${ }^{10}$.

\subsubsection{General Role and Responsibility Includes}

- They must act in good faith and in the interest of the company

- The use of the power of a director must be for proper and justifiable reason.

- The director of a Company must be careful, diligent and skilful and must exercise reasonable decisions.

- A Director shall ensure that the company is a profitable undertaking and venture.

- Complying with the Companies Act and timely performing all the periodical compliances mentioned in the Companies Act.

\subsubsection{Duties of a Director of a Company}

The duties of a director are mentioned under section 166 of the Companies Act, 2013 which lays down the following:-

- Director of a company shall act according to the articles of Association of the company.

- A Director shall act in good faith and for the benefit of the members as a whole.

- Director is also duty bound to take care of environmental laws as well.

- Director must use his all powers diligently and reasonably and not in an arbitrary and non-reasonable manner.

- The interest of a company and the Director of the company may vary but the Director is here duty bound to merge the interest of the company along with theirs.

- When the Director of a Company is making profit at the cost of the company then the Director must be liable to pay an equal amount of profit which the company had lost due to undue gain of the Director.

- Director cannot assign or authorise any person other than him/her to his/her work.

- Director of the Company who act in contravention of the provisions of the Companies Act shall be liable to fine up to 1 lakh rupees which may extend to five lakh rupees.

\section{Insolvency of a Company}

When a company is unable to pay its debt then it is considered as insolvent and insolvency of a company can be assessed either by cash flow insolvency method and balance sheet insolvency method. When a person does not have appropriate assets to pay for what is owed to the lenders/creditors, this situation is cash flow insolvency where as in balance sheet insolvency the person or company does not have money to pay its all the debts.A company that is balance-sheet insolvent may still have enough cash to pay its next bill on time. However, most laws will not let the company pay that bill unless it will directly help all their creditors. For example, an insolvent farmer may be allowed to hire people to help harvest the crop, because not harvesting and selling the crop would be worse for his creditors ${ }^{11}$. Impact of the insolvency of the company includes disqualification of director and increase in the risk of personal claims by the creditors.

\subsection{Investment Fraud in the Company}

Fraud upon the Shareholders of the company and its Impact over the society is quite deep as the number of people involve is quite large and thereby this downfall directly impact the security market on whole. According to International Monetary Fund (IMF), the world wastes up to $\$ 2$ trillion in corruption ${ }^{12}$. While the money invested in the stock market and specifically in the shares of the company with respect to whom financial scam took place. When the scam news is reported into the stock market it will impact the whole of the stock market

\footnotetext{
$7_{\text {ibid }}$

8 (2004) EWCA Civ 1244

${ }^{9}$ (2003) EWCA CIv 810

${ }^{10}$ (2003) BCC 140

${ }^{11}$ https://en.wikipedia.org/wiki/Insolvency, <accessed on 26.04,2018>

${ }^{12} \mathrm{https}: / /$ yourstory.com/2017/12/8-scams-india/<accessed on 25.04.2018>
} 
and also the people who had invested into the shares of that company. This would lead to huge financial loss to the investors who had invested their hard-earned money in the shares of the company. Shares of the Satyam Company plunged $77.69 \%^{13}$ in a single trading session on $7^{\text {th }}$ January, 2009 as Chairman resigned after announcing that Company's accounts were inflated resultantly. Satyam Shares were removed from the S\&P CNX Nifty 50 -shares index from January $12^{\text {th }}$ of January, Satyam had lost 10,000 crore rupees in a single day trading and resultantly 15 shares listed on US bourses bore the burden of negative market sentiments and also witnesses downfall of \$ 1.94 billion in their combined market capitalization. The impact of every financial scam is adverse and it shakes the very ground of financial market.

\subsection{Personal Liability of a Director}

The Director/managing director of a company is the person who is looked upon as the manager of day to day activities of the company so whenever any adverse situation arises in a Company they are the ones who are answerable. Usually Directors of a Private limited Company is not directly held liable for the debts of the Company but in certain exceptional situations they are held personally liable to the creditors. There are various types of frauds by the company but here for the brevity of this research article the frauds which are specifically done by the Director of the company are taken and focused in detail. There is a deep connection between fraud and company's Director which is how theory of lifting of corporate veil is applied. The director of a company holds so much of responsibility towards the working of company that any mishappening will be addressed to him only. There are some circumstances under which Director of a company will be held personally liable during any mishappening. Under these categories the directors can be made liable under companies Act to pay the debts:-

- While balancing the conflict of interest.

- Under the concept of officer in charge, then in case of default he will be held liable.

- When Directors directly signed or contracted any document.

While in some cases quashing of the FIR against the Director is looked upon as one solution to run away from the crime, this issue has been resolved by the Hon'ble Court in Vinod Raghuvanshi Vs. Ajay Arora ${ }^{14}$ and in Maksud Saiyed Vs. State Gujrat \& Ors. ${ }^{15}$, the Court said that quashing of FIR seems justifiable only in some circumstance where the Prima Facie case to proceed against the accused is not made out but act without the connivance of the accused is absolutely rare so decision is based upon the evidence adduced in the trial stands good and justifiable.

\subsection{Personal Liability of Director in Insolvency of Company}

When a company goes insolvent and the company is unable to pay its debt, no matter what there would always be one person who would always be held liable for the loss of money of various investors and creditors as the whole responsibility of running the company and managing the affairs of the company is in hands of the Directors or Director of the company. In these circumstances the Directors being the manager of day-to-day activities of the company will have to answerable to the creditors and investors of the company. The Directors shall prove that they had taken all reasonable steps which could have probably save the company in this worst situation and they must be able to demonstrate that they have taken all possible steps which are under their control to ensure the repayments of all creditors using the resources of the company.

In the following situations they are directly responsible:-

a) When the company is continuously paying the dividend inspite of the fact that it has become insolvent.

b) When director is personally guaranteeing any debt on behalf of company and then knowingly breaching the provisions of the contract ${ }^{16}$.

c) When the Directors are using the company's fund in non-business activity

Before Insolvency and bankruptcy code, 2016 (IBC) there were different overlapping laws that used to deal in financial failures and insolvency of companies and individuals which does not aid lenders in effective and timely recovery or restructuring of defaulted assets and causes undue strain on the Indian credit system. After the Insolvency and Bankruptcy Code, 2016 drafted by Bankruptcy law reforms committee the complexities due to multiple overlapping of the laws has been resolved.

\footnotetext{
${ }^{13} \mathrm{https}: / / \mathrm{www}$. slideshare.net/shijinpv12/financial-scams-impact-on-stock-market-or<accessed on 27.04.2018>

${ }^{14} 2013$ AIR SCW 660

${ }^{15}$ (2008) 5 SCC 668

${ }^{16} \mathrm{https}$ //Www.realbusinessrescue.co.uk/business-insolvency/trading-insolvent-director-responsibilities/can-directors-beheld-liable-for-company-debts-in-a-ltd-company, <accessed on 26.04.2018>
} 


\subsection{Personal liability of Directors in investor Fraud (Scams) Cases}

The concept of fraud not being defined anywhere in the Companies Act, 2013 but it has been defined in the contract Act 1956 under section 17 as "Fraud" means and includes any of the following acts committed by a party to a contract, or with his connivance, or by his agents, with intent to deceive another party thereto his agent, or to induce him to enter into the contract". Through the Finance Bill, 2018, the government amended the Prevention of Money Laundering Act, 2002 (PMLA). The handling of proceeds from corporate frauds will now be a money- laundering offence ${ }^{17}$. The term Fraud is not defined in Companies Act, 2013 but the punishment for fraud is elucidated under section 447 of Companies Act, 2013.

In Sunil Bharti Mittal Vs. $\boldsymbol{C B I}{ }^{18}$, the Supreme Court held that an individual can be held liable for an offence by the company (i) if there is sufficient evidence of the individual's active role coupled with criminal intent; or (ii) where the statute itself stipulates the liability of directors and other officials, such as under the PMLA. Under the Companies Act, an exception has been specifically carved out for independent and non-executive directors, ensuring that they are liable only in cases where their knowledge and involvement can be established or where they, despite having knowledge, failed to act diligently. If a fraud is identified, the banks are required to report it to the state police/CBI/SFIO, depending upon the size of the fraud and type of bank.

In history, the Lehman brothers case up till now has been one of the biggest bankruptcy Case ever witnessed till date which impacted the stock market adversely. According to data provided by www.investopedia.com ${ }^{19}$, On September 15, 2008, Lehman Brothers filed for bankruptcy. With $\$ 639$ billion in assets and $\$ 619$ billion in debt, Lehman's bankruptcy filing was the largest in history, as its assets far surpassed those of previous bankrupt giants such as WorldCom and Enron. Lehman was the fourth-largest U.S. investment bank at the time of its collapse with 25,000 employees worldwide. This bankruptcy case induced huge financial crisis in US market and also contributed to a loss of $\$ 10$ trillion in market capitalization from global market equity in October 2008.lehman's fall roiled Global Financial market for weeks and led to \$ 46 billion of its market value being tripped off the stock exchange.

\section{Case Study}

Under this heading, various recent and also leading case studies of India as well as of International levelare mentioned which even today stood as good examples of investor's fraud and insolvency cases which does not aid lenders in effective and timely recovery or restructuring of defaulted assets and causes undue strain on the Indian credit system $^{20}$.

\subsection{Sunil Bharti Mittal Vs. CBI ${ }^{21}$}

The position of corporate criminal liability is cleared after the decision of Sunil Bharti Mittal's Case in 2015. The main question of law was whether the liability of a company can be attributed to the Person(s) who are managing the day-to -day affairs of the business, and theory of attribution was applied by the Hon'ble Court. Through this decision the Hon'ble Court overruled its earlier decision of Iridium India Telecom v. Motorola $(2011)^{22}$, wherein it was held that,

"the companies and corporate houses cannot claim an immunity from criminal prosecution on the ground that they are incapable of possessing the mensreafor the commission of criminal offences. By way of the principle of attribution, the criminal intent of the alter ego of the company/body corporate i.e. the persons or group of persons in control of the affairs of the company and at the helm of its affairs, can be attributed to the company and the company can be prosecuted. This means attributing the will of the individuals on to the company to attract criminal liability of the corporate body".

\footnotetext{
${ }^{17} \mathrm{https} / /$ www.livemint.com/Opinion/gwAQg5BZaenLohVeKUVLYM/A-directors-liability-in-cases-of-fraud.html, <accessed on 26.04.2018>

${ }^{18} \mathrm{https} / / /$ www.livemint.com/Opinion/gwAQg5BZaenLohVeKUVLYM/A-directors-liability-in-cases-of-fraud.html< accessed on 26.04.2018>

${ }^{19}$ Case Study: The Collapse of Lehman Brothers https://www.investopedia.com/articles/economics/09/lehman-brotherscollapse.asp\#ixzz5E2rrG677 <accessed on 25.04.2018>

${ }^{20} \mathrm{http} / / / \mathrm{www} . \mathrm{mondaq} . \mathrm{com} / \mathrm{india} / \mathrm{x} / 492318 /$ Insolvency+Bankruptcy/The+Insolvency+And+Bankruptcy+Code+2016+Key +Highlights

${ }^{21}$ MANU/SC/0016/2015

${ }^{22}$ https://rahulsiasblog.com/2016/12/14/on-principles-relating-to-corporate-criminal-liability-a-note-on-the-recentjudgment-in-sunil-bharti-mittal-v-cbi-2015/, <accessed on 27.04.2018>
} 
In the Sunil Mittal's case Special Magistrate had observed in impugned order that since Appellants represent the mind and will of each company, their state of mind was state of mind of company and, therefore, on this premise, acts of company were attributed and imputed to Appellants. ${ }^{23}$ In the above-mentioned case three judge bench held that a Director of a company can be held liable only when there is any direct evidence is available against them and not otherwise. The Supreme Court categorically laid down that, "When the company is the offender, vicarious liability of the directors cannot be imputed automatically, in the absence of any statutory provision to that effect." It was surmised that it is a cardinal principle of criminal jurisprudence that there is no vicarious liability unless the statute specifically provides for $\mathrm{it}^{24}$. In earlier decision of the Apex court namely $\boldsymbol{J} . \boldsymbol{K}$ Industries Limited and Others Vs. Chief Inspector of Factories and Boilers and Others ${ }^{25}$ it held that for vicarious liability under strict liability statutes, a person in charge would be deemed to be responsible for the acts of the company. A Similar type of question was also aroused in Ministry of Agriculture Vs. Mayhco Monsanto Biotech (India) Limited ${ }^{26}$ as to whether a Director or any other officer of the company can be prosecuted for an offence without arraigning the company itself as an accused and whether the director along with the company can be prosecuted for an offence.

Whereas in State of Madras Vs. CV Parekh" ${ }^{27}$ the Hon'ble Supreme Court held "that the liability of the person-in-charge of the company is binding when a contravention is committed by the company and if the company is not prosecuted, the person-in-charge of the company could not be fastened with liability". The decision of Apex court in Sunil Mittal's case has been reiterated in HDFC Securities Ltd. \&Ors.v. State of Maharashtra $^{28}$

\subsection{Subrata Roy Sahara VS. Union of India (UOI) and ORS. ${ }^{29}$}

In this recent decision of Apex Court, the legal question aroused was whether the director/officer in-charge of the company will be liable for not complying with the compliance of the Company law, along with the order of detention of the accused for non-appearance in court proceeding. In this case the order of detention of the accused was challenged. In this decision SEBI (Security Exchange Board of India) received one complaint of non-compliance of the provisions of Company law before issuing of Red Herring prospectus while the whole of the investors' money was kept at stake of the jurisdiction of SEBI and ROC. The question was raised on whether the SEBI can investigate in matter of non-compliance of the provisions of the company law. The Apex court through K.S. Panicker Radhakrishnan, J. gave Ratio Decidendi that "Company though a legal entity could not act by itself, it could act only through its Directors". In Para no 29 Hon'ble Apex court stated that "obligations of the Directors in listed companies are particularly onerous especially when the Board of Directors makes itself accountable for the performance of the company to shareholders and also for the production of its accounts and financial statements especially when the company is a listed company".

\section{Conclusion and Suggestions}

\subsection{Conclusion}

This paper will make us understand the role and duties of the Director of the Company. Different fraud and scams are being looked upon with different strategies and how they are being solved or tackle is subject to the interpretation of the court of Law. These kinds of crimes generally put liability of the crime upon the head of the company even when they are not the one who havedone the crime. This study along with various case laws /case study will clarify the doubts as in what are the situations when director of a company is held personally liable for any fraud upon the investor or any scam inside the company will held personally liable to a man who heads the organisation.

After the two leading recent judgements of the Apex court in Director's responsibility the position of vicarious liability of the director or officer in charge is clear and it has been decided that a director/officer-in-charge is distinct from the company and thereby can be held liable only when they have taken any personal liability through signing of any contract or papers, whereas they also cannot be held liable when there is no direct evidence against them.

\footnotetext{
${ }^{23}$ Supra note 14

${ }^{24} \mathrm{http}: / /$ www.mondaq.com/india/x/563958/Directors+Officers/DIRECTORS+LIABILITY+REVISITING+THE+PRINCI PLES+OF+VICARIOUS+LIABILITY, accessed in 24.04.2018

${ }^{25}(1996) 6$ SCC 665

${ }^{26}$ 2016) 137 SCL 373

${ }^{27}$ MANU/SC/0195/1970

${ }^{28}$ (Crl. Appeal No. 1213 of 2016) (SC) (Date of Decision: 09.12.2016).

${ }^{29}$ MANU/SC/0406/2014
} 


\subsection{Suggestions}

The Company law is very vast and specialised area wherein it is difficult to hold the liability of a particular person without knowing the legal provision and the recent decisions of the Court. Corporate professional who are holding office in charge shall follow the following things when in similar position:-

1. The director or any other professional acting in charge shall always seek advice of a lawyer before signing a paper or acting upon any unpredictable situations.

2. They shall not mix their personal interest with professional responsibility.

3. All professional shall know their role and duties upon which they can be prosecuted if not followed.

\section{References}

1. 10-biggest-corporate-scam-of-india. https://www.thecsclubindia.com

2. The Companies Act, 2013, India.

3. www.globalnegotiator.com.

4. https://en.wikipedia.org/wiki/Insolvency

5. https://yourstory.com/2017/12/8-scams-india

6. https://www.slideshare.net/shijinpv12/financial-scams-impact-on-stock-market-or

7. https://www.realbusinessrescue.co.uk/business-insolvency/trading-insolvent-directorresponsibilities/can-directors-be-held-liable-for-company-debts-in-a-ltd-company.

8. https://www.livemint.com/Opinion/gwAQg5BZaenLohVeKUVLYM/A-directors-liability-in-cases-offraud.html

9. https://www.livemint.com/Opinion/gwAQg5BZaenLohVeKUVLYM/A-directors-liability-in-cases-offraud.html

10. Case Study: The Collapse of Lehman Brothers https://www.investopedia.com/articles/economics/09/lehman-brotherscollapse.asp\#ixzz5E2rrG677

11. http://www.mondaq.com/india/x/492318/Insolvency+Bankruptcy/The+Insolvency+And+Bankruptcy+C ode+2016+Key+Highlights

12. MANU/SC/0016/2015

13. https://rahulsiasblog.com/2016/12/14/on-principles-relating-to-corporate-criminal-liability-a-note-onthe-recent-judgment-in-sunil-bharti-mittal-v-cbi-2015

14. http://www.mondaq.com/india/x/563958/Directors+Officers/DIRECTORS+LIABILITY+REVISITING +THE+PRINCIPLES+OF+VICARIOUS+LIABILITY 